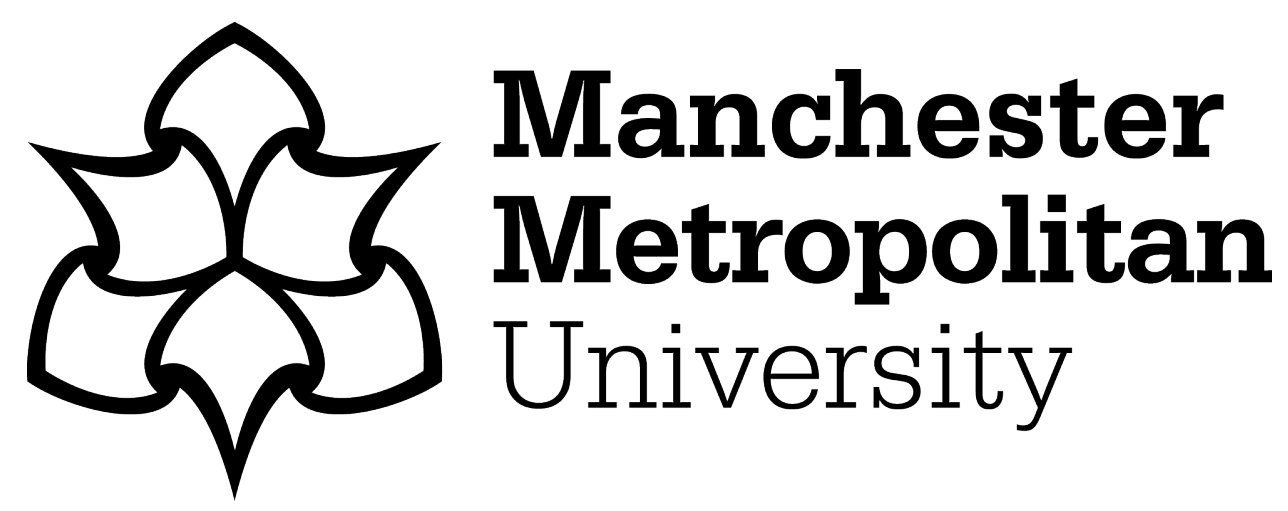

Liggins, E (2018) The "Sordid Story" of an Unwanted Child: Militancy, Motherhood and Abortion in Elizabeth Robins' Votes for Women! and Way Stations. Women's Writing, 25 (3). pp. 347-361. ISSN 0969-9082

Downloaded from: https://e-space.mmu.ac.uk/621022/

Publisher: Taylor \& Francis (Routledge)

DOI: https://doi.org/10.1080/09699082.2018.1473019

Please cite the published version 


\section{THE 'SORDID STORY’ OF AN UNWANTED CHILD: MILITANCY, MOTHERHOOD AND ABORTION IN ELIZABETH ROBINS' VOTES FOR WOMEN! AND WAY STATIONS}

Emma Liggins

Dept of English, Manchester Metropolitan University, Rosamond St West, off Oxford Road, Manchester M15 6LL.

This article re-considers representations of the militant suffragette in two texts by the radical writer Elizabeth Robins, Votes for Women! (1907) and her collection of political speeches and articles, Way Stations (1913). Her plea for twentieth-century women writers to create new roles for women outside those of wives and sweethearts can be read in relation to the creation of her 'exceptional' suffragette heroine, who thrives on her singleness in her 1907 play. Focussing particularly on the taboo issues of abortion and unmarried motherhood, I consider the ways in which Robins developed the fallen woman on stage narrative in the early twentieth century, and how childlessness is shown to be both necessary and problematic for the suffragette heroine. I also reassess Robins' complex commentaries on militancy and 'quiet propaganda' in her suffrage speeches and pamphlets.

The meanings of militancy as a form of political protest have generated considerable discussion amongst suffrage historians and feminist critics. In 2000 Sandra Stanley Holton noted the gaps in our knowledge of the militant tactics adopted by different suffrage organizations. ${ }^{1}$ Writing on the Women's Freedom League founded in 1907, Claire Eustance has explored the elasticity of the term, showing how it encompassed a spectrum of positions from rebellion and "non-violent resistance" to windowsmashing and arson. ${ }^{2}$ Women writers' responses to the suffrage campaign were always informed by an awareness of different forms of political protest, raising broader questions about class, family and femininity. In this article I examine some of the diverse meanings of militancy in relation to abortion, childlessness and the differences between ordinary and exceptional women in the writing of the actress turned activist, Elizabeth Robins, linking this to her involvement with the Women Writers' Suffrage League (WWSL) formed in 1908. A reconsideration of Elizabeth Robins' political arguments about militancy and motherhood, in the context of shifting attitudes towards 
what it meant to be militant between 1907 and 1914, can illuminate the 'sordid story' of a suffragette's lost child in her pioneering suffrage drama Votes for Women (1907). Dramatizing the effects of an illegal abortion, which was subject to censorship in the early twentieth century, allowed Robins to expose stereotypes of the dowdy, childless suffragette as limited and limiting. The significance of "quiet propaganda" and the role of the "ordinary woman" in Way Stations, a collection of suffrage speeches and articles for the press published in 1913, are revealing of Robins' ongoing negotiation of the woman writer's special role in advancing the cause.

\section{The Women Writers' Suffrage League}

As president of the WWSL, a suffragist organization formed in 1908 which dedicated itself to achieving political change by "the use of the pen", ${ }^{3}$ Elizabeth Robins became a trail-blazer for a new kind of heroine. An American actress and novelist who had moved to London in 1888, Robins was primarily known to the British public for her leading roles in the radical drama of Henrik Ibsen, such as Hedda Gabler in 1891. She remained active in both theatrical and political circles, joining the Women's Social and Political Union (WSPU) in 1906 at the end of her acting career, and was admired by the Pankhursts for her suffrage speeches. In her lecture "The Women Writers" at the Criterion Theatre in 1910, she famously urged members of the newly formed League to produce alternative narratives for women outside of marriage and motherhood:

Enough has not been made of such traces as history preserves of significant lives lived by women [...] Your Great Adventure is to report her faithfully. So that her children's children reading her story shall be lifted up - proud and full of hope. "Of such stuff", they shall say, "our mothers were! Sweethearts and wives - yes, and other things besides, leaders, discoverers, militants, fighting every form of wrong". $(178,181)^{4}$

This has generally been read in relation to unearthing these "significant lives" which lie outside conventional notions of women's history, rather than in terms of what is suggested about the relationship between motherhood and militancy. In bequeathing their legacy to their grandchildren, the leaders, discoverers and militants must necessarily position themselves in relation to the next generation and the one after 
that, which involves a confrontation with their attitudes to reproduction. In Robins' writing of the early twentieth century the suffrage heroine's militant characteristics had to be reconciled with her (lost) maternity.

According to her biographer Angela V. John, Robins, a "committed suffragette" and public persona in the Edwardian period, "took on the establishment both from without and from within, becoming an apologist for militancy in the daily press". ${ }^{5} \mathrm{Her}$ American identity set her apart from her contemporaries and, as both insider and outsider, she was perhaps well placed to offer an original insight into the British suffrage movement. Whilst her work for the theatre is more well-known, Way Stations (1913), often ignored by critics, has not been considered in relation to other feminist arguments of the suffrage era about motherhood and singleness. Robins was developing her views on the "exceptional woman" and the militant's embracing of publicity; these can be read alongside questionings of the maternal instinct and the campaign for birth control by other suffrage feminists such as Cicely Hamilton and Stella Browne, the campaigner for reproductive rights. Hamilton, also known as an actress and playwright, had formed the WWSL with Bessie Hatton and was connected with Robins through its sister organisation, the Actresses' Franchise League (1908), dedicated to the staging of suffrage drama. ${ }^{6}$

The woman writer's special role in social reform and legacy for "the Women Writers of the future" (180) is paramount in a series of speeches later included in Way Stations delivered to the WWSL between 1908 and 1910. As Sowon S. Park has shown, WWSL writers believed that their work should be "Interventionist", aimed at the common reader but also "exploit[ing] its potential to bring about social change". 7 The leaflet outlining the function and scope of the society asserts its aim "that members will ensure ventilation of the subject [of the emancipation of women] in such ways as are open to them - by writing articles, taking part in newspaper correspondence, etc." (83) and lists key members, including Olive Schreiner, May Sinclair, Sarah Grand, Beatrice Harraden, Violet Hunt, Mrs Havelock Ellis and Evelyn Sharp. This ventilation is evident in her lecture, "Suffrage Camp Revisited" of 1908, which argues that some women writers of the past have "borne false witness" to women's delight in the domestic. The conservative rhetoric of Sarah Ellis's conduct books in the 1840s is contrasted with Mrs Jamieson's progressive proclamations on woman's desired movement into her "real sphere" outside the home. The fact that Victorian women 
writers had not sufficiently been able to challenge notions of "what is called [woman's] proper sphere" (50), a becomes a call to arms:

What came of all this brave nineteenth-century talk that has to our ears such a twentieth-century ring? Why didn't these women accomplish more? Why have they left so much for you to do? [...] These excellent people failed to further the Cause they advocated, because they tried to do alone what can only be accomplished if we work together. (50)

This critique of the exceptional woman, who tries to go it alone, is coupled with the belief that by working together, "shoulder to shoulder" (53) twentieth-century women writers can inspire woman to move into her "real sphere". In a later speech, connections are made between Mary Wollstonecraft's arguments about women's desire for citizenship and Cicely Hamilton's Marriage as a Trade (1909) which exposes marriage as a form of prostitution. In the latter Hamilton attacked "the ideal of the "silly angel"' before criticising women writers for creating "lop-sided" female characters, "creatures existing only for love and maternity", which leave readers "unconvinced, dissatisfied and even irritated". ${ }^{8}$ Silly angels, like the conventional wives and sweethearts, would not take centre stage in suffrage writing. Although it did not directly discuss politics, Hamilton's play, Diana of Dobson's (1908), allowed the woman writer to ventilate concerns about sweated labour through the speeches of an over-worked shop-girl who dared to stand up to her capitalist employer. Hamilton also pointed out in Marriage as a Trade that "the unwanted child - other than the illegitimate - has played practically no part in [women's literature]". 9 This suggests that she shared Robins' interest in representing the desire for childlessness, as well as addressing concerns about illegitimacy. Robins' urging of women writers "to correct the false ideas about women which many writers of the past have fostered" (85) could be interpreted in terms of asking the League to turn away from conventional notions of marriage and motherhood towards female friendship, militancy and strength through citizenship. 


\section{Votes for Women! and stereotypes of the suffragette}

Suffrage drama, according to Naomi Paxton, flourished between 1908 and 1914 . Plays written and produced by the Actresses' Franchise League, as "unapologetic propaganda pieces", enabled male and female playwrights to move beyond the limitations of the commercial theatre. ${ }^{10}$ Yet propaganda should not be seen as a dirty word, as was sometimes the case in the modernist period; Katharine Cockin reminds us that "women's writing for the stage [...] has been subject to prejudiced judgements" which still need to be challenged by feminist critics". ${ }^{11}$ As members of the AFL, both Robins and Hamilton appropriated the aims of the WWSL for the stage, allowing outspoken and politically aware heroines to eclipse the role of the silly angel. Written in 1907, drawing on Robins' moment of conversion to the cause in Trafalgar Square in 1906, Votes for Women! was one of the first suffrage dramas, staged a few years before suffragette activities escalated into window-smashing and arson. In this new genre, the political woman's embracing of publicity was reflected in new theatrical settings such as the London streets and meeting-halls; Robins' play was praised for its innovative use of a crowd scene of 48 actors set in Trafalgar Square, which mimicked a suffrage rally with all its heckling and interruptions. ${ }^{12}$ Drawing-room discussions often captured women's excitement at entering public spaces and drew attention to this occupation of new territory: the opening address to the audience of Mrs Harlow Phibbs' comic monologue The Mother's Meeting (1913) is "Bit surprised to see me, eh? You'll be more surprised when you hear where l've been". ${ }^{13}$

Comic stereotypes of both suffragists and anti-suffragists featured in many of these plays, as a means of drawing in the audience. In the first drawing-room scene of Votes for Women! a range of characters discuss recent acts by the newly formed WSPU, such as the interruptions of parliamentary speeches and speaking in public about women's trade unions. Differentiating between the dreaded "political women" and "the charming wives and sweethearts who help to win seats", anti-suffragists, including the Liberal MP St John Greatorex, dismiss as "nonsense" the antics of the WSPU, and "that rowdy scene in the House of Commons" (146). ${ }^{14}$ The play sets out to alter misconceptions of suffrage women as "all dowdy and dull" (146) through its "attractive, essentially feminine" heroine, Vida Levering, who we are told in the stage directions is "the kind of whom men and women alike say, "What's her story? Why doesn't she marry?"' (144). One reviewer was puzzled by this mismatch between 
appearance and political integrity, "Why does she wear such charming frocks? Is it to please other women?", adding that "the cause would make more headway [...] if all its advocates were as fair to look on ... and as beautifully dressed as Miss Wynne Matthison", the lead actress. ${ }^{15}$ By doubling the suffragette heroine with the dramatic figure of the woman with a past, Robins detaches the political woman's "rowdiness" from charges of unsexing. The gradually revealed secret of Vida's decision to abort her unborn child, after being seduced by the Conservative MP Geoffrey Stonor ten years before the action of the play, is not the expected explanation for her problematic single status. Robins is unusual amongst suffrage dramatists in using the "abortion story" of her suffragette heroine to bear on her arguments about unplanned pregnancy, childlessness and political reform in the play. As a dramatist angry at the limited roles for women on the British stage, Robins fitted abortion into her radical critique of male sexuality, in order to offer alternative visions of the woman of the future.

This radicalism is toned down in the fictional version of the story, written before Robins was sure of the success of her drama. It is interesting to note that the transformation of the narrative of Votes for Women! into a novel, The Convert, published later in 1907, resulted in more rally scenes (there are four in total, one of which is the scene of Vida's conversion). This allows her to flesh out the transformative experiences of women in the crowd. This is dramatized through Stonor's fiancée, the childlike Jean Dunbarton, in the play, who withdraws her arm from her alarmed lover and presses nearer to the platform before finding her own way through the crowd. Vida's conversion in the novel is described as a mysterious expedition to Trafalgar Square, a place where:

those women, the so-called "Suffragettes", in the intervals of making worse public disturbances, were rumoured to be holding open-air meetings - a circumstance distinctly fortunate for anyone who wanted to "see what they were like" and who was yet unwilling to commit herself. $(71)^{16}$

Attending an organised meeting and taking "those crazy brawlers" seriously is labelled as potentially "compromising" (71), yet the uncommitted reader is also "compromised" in their witnessing of the arguments put forth in favour of citizenship and women's fitness for public affairs. The claiming of the word suffragette as a "badge of honour" 
by one of the speakers - "we accept the clumsy label; we wear it proudly" (89) - may reflect pride in non-violent forms of militancy in the early days of the WSPU.

In the play there is some confusion about the heroine's status, whether she operates as a militant suffragette or a suffragist who prefers more peaceful methods of protest. Most critics see her as a suffragist, if a rather artificially attractive one, with Penny Farfan criticising Robins' "tactic of employing the figure of the "womanly woman" to score feminist points". ${ }^{17}$ The debunking of stereotypes about women protesters, however, keeps it ambiguous; though Vida never openly advocates violence, her alignment with Ernestine Blunt, who thanks men for "calling us female hooligans" (173) in the rally scene, may suggest something different. More conservatively, the novel positions Vida's childlessness as problematic by showing her playing with small children and being admonished by her servant for her failure to reproduce: "I've counted a good while on looking after children again some day. But if you won't get married -" (34). In the novel, the politically significant process of conversion and the need for women to enter the public sphere is given priority over a critique of motherhood.

This may have something to do with issues of censorship and sexuality. Robins, who signed her name on a letter to The Times about the censorship of drama in $1906,{ }^{18}$ was clearly interested in using controversial subject matter and new settings to challenge theatre audiences. The Times reviewer was sceptical about the effectiveness of addressing taboo sexual issues in propaganda: "Whether [...] the cause Miss Robins has at heart is likely to be advanced by hanging it onto other questions of seduction, abortion and infanticide is perhaps doubtful". ${ }^{19}$ At a time when abortion and infanticide were only referred to obliquely in fiction, they were risky subjects for the stage ${ }^{20}$ Critics such as Sheila Stowell have speculated as to why the director of Votes for Women! Harley Granville-Barker's own play Waste (1907), with its abortion references, was refused a licence in the same year that Robins' play was staged in public. ${ }^{21}$ Robins had represented an infanticidal mother in the disturbing New Woman play, Alan's Wife (co-written with Florence Bell) in 1893, but both women authors felt it prudent to remain anonymous. ${ }^{22}$ Smuggling the abortion question into the new genre of suffrage drama, in which the political content might or might not act as a smokescreen for its protest against women's lack of reproductive rights, remained a risk. 
"Spectatorship in the theatre", argues Viv Gardner, "is not neutral", particularly at a time when female spectators still did not have the same ease of access to the London theatres as men. ${ }^{23}$ The gender dynamics of audiences for suffrage drama has received some attention, particularly in terms of the female matinée crowd with the leisure to occupy theatrical space in the afternoons. Penny Farfan writes of the "sympathetic and predominantly female audience at the Court Theatre", although it is worth pointing out that the extension of the run to evening performances would have made it more open to male spectators. ${ }^{24}$ Robins' reputation as an Ibsen actress, coupled with the avant-garde character of the Court Theatre and Granville-Barker as director, might have attracted a more feminist audience; Granville-Barker's advice to change the title from A Friend of Woman to Votes for Women! (to match the slogan displayed on the banners in Act Two) also put the play's suffrage credentials upfront. ${ }^{25}$ The Era reviewer suggested that the audience extended beyond supporters of the suffrage by asserting "if Votes for Women does not have the effect of altering opinions as to the question of female suffrage, it will, at any rate, show the women's side of the question in a fresh light to most playgoers" ${ }^{26}$ It was risky for women to be seen at both political rallies and at suffrage dramas, as putting themselves forward as spectators in public arenas organised around conversion was potentially compromising. Prepared to court controversy with her subject matter, Robins would certainly have been hoping not only to alter opinions about female suffrage but to make her audiences think about how motherhood and unplanned pregnancy affected women's capacities to join the fight. 


\section{Motherhood and the "sordid story" of abortion}

The controversial subject of abortion needs to be seen in the context of earlytwentieth-century debates about motherhood and contraception. At a time when the eugenics movement was advocating the sterilisation of the unfit in the service of a healthier population, counter-arguments about the woman's right to restrict her own fertility were voiced in the radical press. The middle-class woman's access to contraceptive advice before the first birth control clinics in London in the 1920s was limited and incomplete, but the demand for this advice was certainly growing. ${ }^{27}$ The tireless campaigner for abortion rights, Stella Browne, encouraged the separation of motherhood from a woman's duty. Her letters to radical periodicals such as Dora Marsden's The Freewoman (1911-1912) advocated the wider availability of birth control. She argued that "the Woman who is passionately and pre-eminently maternal shall not be condemned to childlessness through economic pressure and medieval convention, yet our right to refuse maternity is also an invaluable right". ${ }^{28}$ These rights of refusal were further articulated in Browne's important pamphlet Sexual Variety and Variability among Women (1917) where she claimed that "much actual motherhood is unwilling [...] the underhand opposition to the spread of contraceptive information must be overcome. The ineffably foolish laws penalising abortion must be abolished". ${ }^{29}$ However, as Lucy Bland has pointed out, although "most feminists were in favour of sex education as one important element in the long-term solution to male sexual behaviour", many of them recommended chastity rather than birth control. ${ }^{30}$ Christabel Pankhurst's modification of the famous slogan "Votes for Women" to "Votes for Women, Chastity for Men" in her The Great Scourge and How to End It (1913), which publicised the spread of syphilis in marriage, is an example of this approach.

Suffragist writers pondered the links between maternal status and activism, with some figures attributing their dedication to the cause to their childlessness. In Marriage as a Trade, Hamilton identified degradation as the other side of the picture of "the beauty and sanctity of motherhood", and protested against the training of women to be "unintelligent breeding-machines". ${ }^{30}$ In her autobiography Life Errant (1937), she articulated her childlessness in relation to the ongoing threat of world war, making the choice not to bring children into an unstable society: "I am well content to have no younger generation to fear for". 32 Her celebration of the independence of the single woman seems inseparable from her achievements as a woman writer and 
activist. In The Great Scourge, Pankhurst captures this revaluation of the spinster: "Nowadays the unmarried women have a life full of joy and interest. They are not mothers of children of their flesh, but they serve humanity, they can do work that is beautiful and useful. Therefore their life is complete". ${ }^{33}$ Both Hamilton and Pankhurst concur that the singleness of women is valuable for the transformation of society.

Within the context of broader discussions of birth control in the 1900s and 1910s, debates about abortion and unplanned pregnancy were used to mediate a range of feminist arguments about the relationship between women's political helplessness and their lack of control over their fertility. Changing perceptions of the unmarried mother, who was increasingly recognised as a figure in need of feminist help and state support, also influenced this thinking. If the helplessness of women is "The greatest evil in the world" (149), as Vida claimed in the play, then women's helplessness is often shown to stem from unprotected and uninitiated sex. The political arguments in Way Stations gathered weight from feminist condemnation of "Sex-Antagonism", or men's abuses of their sexual power, both within and outside marriage. Robins reflected: "the Suffrage agitation has brought [sex-antagonism] out of hiding ... The evil of bad relationship between the sexes is not the new thing. The attack upon it is the new thing" $(267,268)$. The consequences of unprotected sex dramatized through the revelations of Vida's secret past in Votes for Women! become part of an attack on sex-antagonism by the connections between her individual story and the case histories of wronged women; these were used in the political speeches of the play or passed down from older to younger women in the drawing-room.

The passing of stories of seduction between women is framed in terms of hidden knowledge, which the older generation prefer to keep hidden:

Miss Levering: The girls who need shelter and work aren't all serving-maids.

Mrs Heriot (with an involuntary flash): We know that all the women who - make mistakes aren't.

Miss Levering (steadily): That is why every woman ought to take an interest in this - every girl too.

Jean/Lady John\} (simultaneously): \{Yes - oh, yes!/No. This is a matter for us older - 
Mrs Heriot (with an air of sly challenge): Or for a person who has some special knowledge. (Significantly) We can't pretend to have access to such sources of information as Miss Levering.

Miss Levering (meeting Mrs Heriot's eye steadily): Yes, for I can give you access. As you seem to think, I have some first-hand knowledge of homeless girls. (151-2).

It is significant that attempts to shield the younger girl from the truth fail here (Lady John's "No" is drowned out), resulting in the suffragist granting access to the ways in which women might make sexual mistakes. The other women associate this first-hand knowledge with "these horrors" (153), though as in the rally scene it is important that Jean as a potential convert hears what is usually repressed in polite society. Mrs Heriot later passes the "delicate", "sordid story" onto the "horribly ignorant" girl who only half understands. The unspeakability of abortion underpins the lending of a large sum of money and the discovery of Vida, "horribly ill" in a lonely Welsh farmhouse, after being visited by a "shady-looking doctor - nameless, of course. And then this result" (154). If abortion is framed as sordid and shameful by the older generation of women, Jean's unexpected response that Vida's campaigning for homeless women should then be seen as a sign of "courage" rather than "effrontery" is significant, given her hidden history; it shows the possibilities for a radical reconfiguration of the next generation's understandings of reproductive rights.

Narratives of seduction, unplanned pregnancy and the risks of prostitution amongst homeless women which circulate in the play demonstrate that female solidarity is needed to raise awareness of sexual dangers. In her Trafalgar Square speech Vida's tale of the working-girl, who "crawled with the dead body of her newborn child to her master's back-door" (184) before being tried for infanticide by an allmale jury, ends with her acknowledgement of the need for kinship with "our unfortunate sisters" and "every woman who has borne a child" (185). As Joanna Townsend has argued, this is a plea for "co-operation by women with women and for women", as the heroine "is able to connect her experiences of seduction and the maternal body with the more general experiences of women". ${ }^{34}$ Drawing on material from Mary Higgs' exposé of destitution and prostitution, Three Nights in Women's Lodging Houses (1905), Robins also gives another example of the servant seen dying in a Tramp Ward 
who becomes a victim of seduction after missing the last train back to her employer's house and "the wrong person found her crying on the platform" (150). However, the concept of shame is reworked in Vida's modification of her seduction narrative as reported to Jean: "All she ever said was that she was ashamed ... ashamed that she 'hadn't had the courage to resist' - not the original temptation but the pressure brought to bear on her "not to go through with it'" (154-5). Rejecting the equation of political freedom with "sex freedom" in The Great Scourge, Pankhurst proclaimed that women "know too well what is the harvest of wild oats ... In the opinion of the Suffragettes sex is too big and too sacred a thing to be treated lightly". ${ }^{35}$ But Robins retreats from this position of radical celibacy in her play, showing how her heroine remains unashamed of being "tempted" into a sexual affair, inviting her audience to reject Mrs Heriot's view that an unmarried mother is "not a desirable companion for a young girl" (155). Aligning her with other oppressed mothers who pay the social price for unprotected sex, despite knowing the risks involved, Vida's story also functions as a plea for wider availability of birth control.

In the final act Robins addresses the complex question of maternal loss in relation to political women's claiming of a voice. Rejecting the pity of society for her lack of husband and child, the suffragist's claim to her own voice becomes inseparable from her rewriting of "her own poor little story": "The only difference between me and thousands of women with husbands and babies is that I'm free to say what I think. They aren't' [emphasis in original] (198). Whilst this again locates freedom of speech with the childless, it seems at odds with Vida's sense of loss in the final confrontation between the former lovers. Sos Eltis has analysed this scene in relation to the text's status as an example of a late "fallen-woman play" in which "in the hands of a newwoman playwright" the fallen woman evades suicide and shame, her "private grief transmute[d] into political conviction". ${ }^{36}$ Vida's often-quoted speech about "one woman's mishap" acquiring broader resonances, certainly becomes instrumental in influencing the male politician to vote for women's suffrage: "What general significance has my secret pain? Does it "join on" to anything?" (207). Yet critics have not paid enough attention to the references to lost maternity in the scene. Within forty lines the word "child" recurs seven times, coupled with notions of sacrifice and wrong. The stage directions indicate her "anguished face", as Stonor, who never knew whether the baby lived or died, is held responsible for the loss: "You can never give me back my child" 
(207). Maternal anguish is evident in Vida's recalling the sound of the dead baby crying: "I used to lie there in that lonely farmhouse pretending to hush it. It was so I hushed myself" (203). This traumatic image is followed by her playing of her trump card: "the ghost of a child that had never seen the light, the frail thing you meant to sweep aside and forget" (203) which will instead secure his political support. However, her defiance of his power, "You can't kill this new spirit among women" (205), implies that her militancy is strengthened because of her loss; the "ventilation" of lost motherhood ensures that her voice is no longer hushed. Her bargaining with him is also couched in terms of the superiority of the childless with their capacity for political action:

Since men alone have tried and failed to make a decent world for the little children to live in - it's as well some of us are childless [...] we are the ones who have no excuse for standing aloof from the fight (208) [emphasis in original].

Such a closing speech, with its emphasis on the "we" suggesting the size of this group, evokes current recoinings of the notion of the childless to the childfree, emptying the term of connotations of failure and lack in order to stress its social and political possibilities.

\section{Militancy and "quiet propaganda" in Way Stations}

Way Stations, a "readable" and "persuasive" account of the suffrage movement, which "takes us ... into the heart of the conflict"37 maximised its appeal because of the way in which Robins manoeuvred between suffragist and suffragette positions, advocating both "quiet" rebellion and more violent methods such as windowsmashing and arson. The American title, referring to local stops along a railway, is linked to its innovative structure: ${ }^{38}$ interwoven with public speeches, letters to the press and articles was one of the first "timetables" of the suffrage movement between 1905 and 1912. Descriptions of events such as imprisonments, parliamentary debates, key speeches and arrests are interspersed with autobiographical fragments under short sections entitled "Time Table". Claire Tylee's misleading classification of the text as political autobiography is less useful than her 
claim that it was a celebratory "history which prioritises the WSPU", though this label also needs qualifying. ${ }^{39}$ In the "Author's Note", Robins casts herself as a hesitant if admiring onlooker at militancy, "never having been one of the more active participants in the events dealt with by this book". However, by reinforcing her "infrequent appearances in print, or on platforms" at times of crisis, this note validates alternative forms of participation. Whilst making no apologies for violence, in "Why", a WWSL pamphlet which also appeared in the journal Votes for Women in 1909 , she also articulates "what passes through the mind of many a quiet, homekeeping, non-militant woman in England to-day" (138), ${ }^{40}$ aligning herself with those whose rebellion took other forms. One anonymous American reviewer of Way Stations worried that "her zeal for the cause carries her, in the defense of militancy, further than most of us would be willing to follow", but conceded that the work "emphasizes the strength of the woman's movement and makes us feel wholesomely ashamed of ourselves for not knowing more of it than we do". ${ }^{41}$ Catering for a range of readers from members of the WSPU and the WWSL to the quiet, non-militant woman, Way Stations is perhaps less a defence of militancy than a recognition of the different ways in which women could participate in the cause.

Shifting understandings of militancy and conversion underpinned the speeches and articles in Way Stations written between 1909 and 1912. According to Angela V. John, who has detailed Robins' habit of dressing rioting up with eloquent words, "her stance on militancy was both clear and problematic". ${ }^{42}$ By 1912, resurgence in WSPU militant protests, in the form of arson and destruction, prompted public disagreements between Teresa Billington-Grieg of the Women's Freedom League and the Pankhursts. The distinctions between the two societies were sharpened as the WFL "endorsed a policy of militancy without violence". ${ }^{43}$ Her timetable for November 1912 links the WSPU's damage to property and window-smashing with increased support for the cause. In a particularly pro-WSPU 1912 speech reproduced in Way Stations, she locates "the new solidarity among women" (222) and their "indomitable' spirit" (223) in more extreme forms of militancy, including law-breaking and violence against property. But this potentially problematic sanctioning of violent militancy is always tempered by a recognition of the cross-class appeal of rebellion, because it allows women to step outside social restrictions. In "Why", she ponders why "women of all classes in England" have felt compelled to join the Cause, exposing themselves to 
danger from the police and showing themselves to be "ready to accept the alienation of many of their friends and most of their menfolk" (102). The following discussion of sweated labour, unequal pay, conditions in workhouses and the injustice of the legal system justifies this acceptance of alienation, because it frees women from the private sphere. She conceives of the "well-bred girls" and "older women" who sell Suffrage papers in the streets as not only "bearing witness" to their faith in the Cause but overturning assumptions that it is only natural for women to shrink from publicity: "So well have women been drilled in the idea that it was undesirable and dangerous for them to do work in public (save as ministrants to pleasure)" (133).

The suffering of mothers and children remains crucial to her defence of militancy: "Men in high places continue to advise 'quiet propaganda' to women whose friends have grown grey practising quiet methods, to women who know what delay means to wives and mothers in the Potteries, to the shop-girl forced on the streets, to the pallid army of workhouse children" ("Why", 139). A 1912 article, 'Sermons in Stones' (included in Way Stations) protested against the conditions of babies in workhouses who never see the light of day, "the absence of State-trained midwives" (240) and the enforced drudgery of working-class mothers, showing her ongoing commitment to better provision for mothers. In the conclusion to her 1912 speech in the Albert Hall, she appeals for "the help of the ordinary women": "You who have not up to now recognised the need of women's direct share in public affairs - you must see that leaving other women's interests entirely to men is unfair to men, as well as horribly dangerous for women" (254). Robins' distinction between the "open or secret aiders and abettors of Militancy" (270) suggests that there were those who offered support but were unable to declare their sympathies for acts of violence. Her passionate commitment to getting these secret advocates, the ordinary women, to subscribe stemmed from her position as a woman writer, whose interrogation of the meanings of militancy in political speeches, fiction and drama fulfilled the interventionist ideals of the WWSL.

\section{Conclusion}

In her "Time Table" for 1908, Robins sets herself apart from "the usual houseparty argument and the usual condemnation of militant tactics", preferring to take her 
place on a cart alongside Mrs Pankhurst in a "rough quarter" (60) of Newcastle. Her own most significant militant tactic was to take up her pen to challenge what she called "drawing-room misrepresentation of the Suffrage scenes" (61). Suffrage drama often revolves around unanswered questions, according to Cockin, resulting in open endings, as "the unresolved conflicts and uneasy tensions in the plays symbolise the problems which could not yet be fully articulated", and the wider social determinants of women's voteless status. ${ }^{44}$ In its confrontation with the taboo subject of abortion, and the lost child that enables political change, Votes for Women! raised complex questions about motherhood, militancy and childlessness which are not entirely resolved. By 1913 her protest against "quiet propaganda" remained inseparable from her demands for better conditions for mothers and the ordinary woman. Her radical staging of her militant heroine's struggle to find a voice fit for both the platform and the drawing-room resonates with her advice to the Women Writers' Suffrage League to correct false ideas about women, in order to inspire the women writers of the future.

\section{NOTES}

1. Sandra Stanley Holton, "Reflecting on Suffrage History" A Suffrage Reader: Changing Directions in British Suffrage History, ed. Claire Eustance, Joan Ryan and Laura Ugolini (London and New York: Leicester University Press, 2000), pp. 20-36 (29).

2. Claire Eustance, 'Meanings of Militancy: the Ideas and Practice of Political Resistance in the Women's Freedom League, 1907-14' in The Women's Suffrage Movement: New Feminist Perspectives, ed. Maroula Joannou and June Purvis (Manchester: Manchester University Press, 1998), pp. 51-64 (59, 62).

3. WWSL leaflet, reproduced in Elizabeth Robins, Way Stations (1913; London: Dodo Press, 2010), p. 82.

4. All quotations are taken from Robins, Way Stations.

5. Angela V. John, Elizabeth Robins: Staging a Life, 1862-1952 (London: Routledge, 1995), p. 3.

6. Sowon S. Park, 'Doing Justice to the Real Girl': The Women Writers' Suffrage League' in Eustance et al., A Suffrage Reader, 90-104, (p. 94).

7. Park, pp. 94, 95.

8. Cicely Hamilton, Marriage as a Trade (1909), reprinted in Controversies in the History of British Feminism: The Workers, Women and Labour ed. Marie Mulvey Roberts and Tamae Mizut (London: Routledge, 1995), p. 225.

9. Hamilton, Marriage as a Trade, p. 236.

10. Naomi Paxton, "Introduction", The Methuen Drama Book of Suffrage Plays (London: Methuen Drama, 2013), pp. vii, ix.

11. Katharine Cockin, "Women's suffrage drama" in The Women's Suffrage Movement: New Feminist Perspectives, ed. Maroula Joannou and June Purvis (Manchester: Manchester University Press, 1998), p. 131.

12. Sheila Stowell, A Stage of their Own (Manchester: Manchester University Press, 1992), p. 14.

13. Mrs Harlow Phibbs, The Mother's Meeting (1913) in Paxton, p. 101.

14. All quotations are taken from Elizabeth Robins, Votes for Women! (1907) in The New Woman and Other Emancipated Woman Plays, ed. Jean Chothia (Oxford: Oxford University Press, 1998).

15. "Review of Votes for Women!, by Elizabeth Robins", The Times, 10 April 1907: 5.

16. All quotations are taken from Elizabeth Robins, The Convert, ed. Jane Marcus (1907; London: The Women's Press, 1980). 
17. Penny Farfan, Women, Modernism and Performance (Cambridge: Cambridge University Press, 2004), pp. 27, 29.

18. See John, Elizabeth Robins, p. 148.

19. "Review of Votes for Women!", The Times: 5.

20. For a discussion of censorship and indecency in this period, see Celia Marshik, British Modernism and Censorship (Cambridge: Cambridge University Press, 2006), pp. 1-7.

21. See Stowell, p. 15.

22. For more on the reception of this play, staged at Terry's Theatre in 1893, see John, Elizabeth Robins, pp. 87-90.

23. Viv Gardner, "The invisible Spectatrice: Gender, Geography and Theatrical Space", Women, Theatre and Performance: New Histories, New Historiographies, ed. Maggie B. Gale and Viv Gardner (Manchester: Manchester University Press, 2000), pp. 25-45 (28).

24. Farfan, p. 32.

25. Stowell, p. 15

26. "Review of Votes for Women! by Elizabeth Robins", Era, 13 April 1907: 13.

27. Lesley Hall, "The Suffrage Era, 1902 to 1918" in Outspoken Women: An Anthology of Women's Writing on Sex, 1870-1969 (London: Routledge, 2005), p. 37.

28. Stella Browne, Letter to The Freewoman, 1 August 1912: 217-18.

29. Stella Browne, "Sexual Variety and Variability among Women" (1917), quoted in Hall, Outspoken Women, pp. 78-9.

30. Lucy Bland, Banishing the Beast: English Feminism and Sexual Morality, 1885-1914 (Harmondsworth: Penguin, 1995), p. 248.

31. Hamilton, Marriage as a Trade, p. 72.

32. Cecily Hamilton, Life Errant (London: J.M. Dent, 1935), p. 286.

33. Christabel Pankhurst, The Great Scourge and How to End It, (1913), pp. 131-2. Quoted in Hall, p. 57.

34. Joanna Townsend, "Elizabeth Robins: Hysteria, Politics and Performance", Women, Theatre and Performance: New Histories, New Historiographies, ed. Maggie B. Gale and Viv Gardner (Manchester: Manchester University Press, 2000), pp. 102-120 (116).

35. Pankhurst quoted in Hall, p. 51.

36. Sos Eltis, "The Fallen Woman on Stage: Maidens, Magdalens, and the Emancipated Female", The Cambridge Companion to Edwardian Theatre, ed. Kerry Powell (Cambridge: Cambridge University Press, 2000), pp. 222-236 (234).

37. "Review of Way Stations, by Elizabeth Robins", North American Review 198: 692 (July 1913), p.142.

38. Angela V. John, "Way Stations Revisited", Women's History Notebooks 3:1 (1996), 34-6 (p. 34).

39. Claire Tylee, "Way Stations to Political Wilderness - The Political Autobiography of Elizabeth Robins", Women's History Notebooks 2:2 (1996), pp. 24-37 (28). In her response, John disproved the theory that the text functioned as a political autobiography. See Angela V. John, "Way Stations Revisited", p. 35.

40. 'Why' was then reprinted in Way Stations.

41. "Review of Way Stations", p. 142.

42. John, Elizabeth Robins, pp. 158, 159.

43. Eustance, p. 59.

44. Cockin, p. 134. 